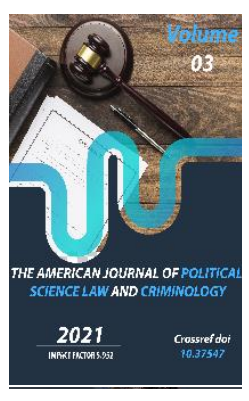

\title{
Image-Building Poiltical Media Text
}

Mokhira Eshanova Yuldashbaevna

Senior Teacher Of Specialized Branch Of Tashkent State University Of Law, Tashkent, Uzbekistan

Journal Website: http://usajournalshub.c om/index,php/tajpslc

Copyright: Original content from this work may be used under the terms of the creative commons attributes 4.0 licence.

\section{ABSTRACT}

The paper discusses issues related to the analysis and application of theory in the field of media linguistics and political linguistics, which is considered the core aspect of the image-based political media text as one of the main means of creating a political image.

Language is a system that constantly changes, performs tasks such as expressing the opinion of society, studying, and communicating information. It is also a specific socio-cultural tool for the storage, aggregation and delivery of information, human activity, management of behaviour. Policy and its institutions cannot accomplish their goals without language opportunities in the society. At the same time, the language itself is also influenced by policy in this or that way. It is known that language becomes an object of individual policy and planning by a state.

\section{KEYWORDS}

Image-based political media text, political linguistics, upper text, intentions, political propaganda

\section{INTRODUCTION}

A text is a unit of meaning for interpretation and understanding. As such, most things are (or could be treated as) texts. Within media studies, a text could be a TV program, film, 
video game, website, book, song, podcast, newspaper article, tweet, or other applications. Texts matter because they are bearers of communication and movers of meaning. Texts can inspire and delight, or disgust and disappoint, but more importantly they intervene in the world and into culture, introducing new ideas, or variously attacking or reinforcing old ones. Textual analysis has long been a primary mode of “doing” media studies. [1]

The concept of "image-based political text" covers promotional texts used in propaganda and advertisement for specific purposes. Such texts will always contain selected and optimized information on political activities. Besides, in the political message there is information about election campaign or the activities of political leaders, people's deputies, etc. In the process of democratic elections, the role and importance of advertising in the introduction of the image of candidates from the same political parties to people in the polling stations is great. After all, the political image of a candidate in advertising should be comprehensively expressed. It includes information on the candidate's profession, work experience, work carried out, achievements, and awards.

It can be also seen through demonstrating public speech related skills in the political discourse. On this stage a person develops his/her political intellectual culture. It also enhances the skills on how to link ideas, making up consistent idea and creating new relevant ideas. In this regard, by means of analyzing Shavkat Mirziyoev's, the president of Uzbekistan, speeches and addresses one can be evident that he is able to objectively and accurately evaluate current socio-political events as well as pass them on to the public. In particular, the President's addresses in the meetings hold in the Cabinet of Ministers, the Senate, the Legislative Chamber, and his speeches in the regional sessions show thorough preparation as he provides clear facts and figures, subsequently, putting forward clear cut tasks, and occasionally using some jokes to encourage high spirit of the public, prove that he can do it very skillfully.

\section{DEVELOPMENT AND ANALYSIS}

Upper text is understood as normal/abnormal criteria with a clear positional, characterized by a targeted modal device, combined in terms of thought, texts, limited space, meaning and situation. Any political message is a subject to an upper text. It is evident that political news is reported in the media at least once a day. If this message carries significant content, it attracts great attention of public. More and more information will be given about the variants of percussion in different genres. The horizontal and vertical attitude to the upper text embodies itself intertextuality delimitation. For Example, J. Fiske says a horizontal text is about a set of interrelations, plot or a person. [2] In vertical intertext there is a connection between the first, second and third text. Upper text is a targeted education, divided into two main high text: theme and modal.

There are both open and closed types of upper texts. Closed text differs in that it is mandatory to complete, and open text is not completed. In the upper text it is possible to talk about the author (the goal will be clearly aimed at the author).

In our view, political messages appear as an upper text (a text denotator - a candidate, a party, acting as a political leader) as follows: 
the fact that the media gives a certain period for participation in the election campaign, the non-existence of direct propaganda, the emergence of international opinions about political leaders, the processes that took place before elections. In addition, if addressor and addressee are evident, the communicative circle of political messages will be enlarged. Ultimately, the people not only imagine different political realities, but also form a healthy competition between them. In this way, political messages are considered an upper text, expressing in itself the unity of thoughts. Political texts are limited, the content is manifested harmoniously. General audience is targeted when it comes to actual political problems. In this regard, it is appropriate to bring the following definition to the political text within the framework of the topic: "Political text is the text:

- Carrying out its functions in the field of politics;

- Having specific topics related to various political problems;

- Created by a person engaged in political activities;

- As a rule, a team of authors and many who have an addressee;

- In order to get a clear result, primarily it is a text that is intended to influence people." [3]

In fact, it seems that this definition refers to the implementation of theoretical, practical and ideological communication tasks of the political text. In the political text there is a description of the tasks, which should be mutual communication between the object and the subject, reasoning and giving importance to it.
The topics raised in the political text; the problems are important for modern political life. And the generality of the political text comes from the circumstances. If the political audience is considered the main subject of the political process, the text will also be of political importance. Because, as a rule, strategic and tactical tasks are assigned to the political text. Any political text, a strategic plan, will be aimed at changing the existing power or supporting it. But the actual text will focus on understanding strategic issues and will relate to the election campaign and other political organizations according to the rule. Part of the political texts perform tactical tasks, [4] such as urgent political tasks, political struggles, the choice of information, the effort to make decisions taken, the influence on a particular person, the exact system and institutions. Therefore, in real life, political texts perform the following functions:

1) It is important to draw attention to the text, but this is an optional task. For some genres it plays a decisive role;

2) Ideological task focuses on that the author of the text chooses or regulates those problems;

3) To convince the audience of the urgency of the problem posed and the proposals for their solution are among the important tasks. The political leader, above all, seeks to convince the audience that his opinion is correct. Here, initially it must be substantiated that the problem is relevant. Secondly, it should be described to people that the audience, along with understanding it, must be able to feel its participation in reality. That is, the politician must explain in an incredibly understandable and folk language. In the third, it is necessary to prove that the 
decision taken for the audience is exactly his own decision. To do this, the text should carry a new meaning using different arguments;

4) To support the proposal of a political leader. A listener or reader should not only believe in the position occupied by the political leader, but also be able to give the politician the necessary votes. Mobilization is carried out not with a logical conclusion, but with emotion. The reason for the latter is that the source is normally chosen and it influences on the sense faster rather than on the mind. In this sense, the linguist scientist G.Pochepsov believes that in the creation of different texts, the author's mental state also has a special influence, which, in one way or another, is reflected in the text. [5] Naturally, in the creation of literary texts, the spiritual state of the author, free from external impressions, contributes to the fact that he can clearly express his spiritual experiences in the product of his creativity. And in the creation of a political text, the author tries to hide some of his feelings, having a high sense of responsibility in it, because the text is directly related to politics, and reacts to an event or phenomenon. This brings out some stylistic challenges for the study when analyzing political texts in contrast to other texts. Here, it seems that the author does not take into account the fact that the statement of the political text and the responsible approach to political texts in its preparation are primary demands, while the purpose of the literary text is mainly educational, giving aesthetic pleasure.

It will be possible to assess the activities of any party, to determine the attitude of a particular political leader to a particular political situation by identifying the point of view of either situation and ways of resolving it. But the person who sets the goal is the customer. The tasks set before him clearly determine the purpose of his approximate activity on the issue. The analysis, the issues identified, will be addressed to the attention of the institutions concerned. For example, in order to come to a single conclusion in improving the system of Higher and secondary special education in Uzbekistan, international educational standards are accepted as a benchmark.

Media text is a PR text written by an PR servant and is characterized by the fact that it is transmitted through the media to the segment of society for identification. [6] In order to formulate specific effective ways of solving political problems, it is necessary to correctly direct and support the subject of positive image, appeal to the mass audience and disseminate it through the media in political mediatext. This concept includes PR and advertising texts. These texts are constantly created by the subject of political activity, embodying in itself the choice and optimized information. In this sense, image-building political text provides information to the society about the positive experience and opportunities of the subject of political activity. It also gives a society an understanding of the subject and state of that politician. The formation of a positive state by providing information creates a certain skill in relation to political activity or political behavior in front of the audience. Naturally, the purpose of political text, in particular, the image-building one is not only to deeply study, analyze, evaluate political processes and to see the future, but also political texts reflect the processes related with the author's interests, 
aspirations and goals, worldview and other characteristics.

Political text plays a significant role in forming and developing the essentials of youth's political thinking and politival overview which helps bring them up the ones who have independent personal opinion and capable to resist against external spiritual and ideological attacks. It also can be used as tool for protecting the youth from the evil oriented intentions against our national political interests and our mode of life through organizing the activities focused on enlarging their political awareness. To do this, our youth must not be indifferent to political processes taking place in the society. In 78his work of "Donishnoma" (The Wise Stories) Abu Ali Ibn Sino defines theoretical and practical knowledge, here he divides practical knowledge into three, the first is governing the country and the second one is related with managing the household. He says that a person might skip those two types of knowledge, however he must be confident that he possesses the third one, self-control, by asking himself such questions as "Why was I born? What is the goal of my life? What have I given to my motherland and the people?". The latter has the power to make a person to be conscious and stand against being careless, indifferent and blind imitation, versus developing humane qualities. [7]

\section{CONCLUSION}

In conclusion, political language is not only a means of communication between people, but also performs a political task. That is, any phenomenon that occurs in socio-political life, regardless of what period it is, political ideas are transmitted to future generations through language. Political language plays an important role in reflecting the spirit of the era, in the individualization of the language of politicians, in giving their spiritual livelihood, in indicating their spiritual level.

Language at the level of political propaganda is quite abstract. The reason is that it is intended for as wide an audience as possible. In it, the slogans occupy a special place. They are extremely functional words, an integral part of popular speech in the field of thought formation and transformation.

\section{REFERENCES}

1. Gray, J. (2017). Text. In Gray J. \& Ouellette L. (Eds.), Keywords for Media Studies (pp. 196-200). New York: NYU Press. Retrieved November 4, 2020, from http://www.jstor.org/stable/j.ctt1gko8zz.6 8

2. Fiske J. Television Culture. London: Routledge, 1987.

3. Репина Е.А. Политический текст как средство речевого воздействия. http://www.psyh-

portret.ru//collection/repina.html .

4. Ражабов Ф. Сиёсий матнлар тахлилининг баъзи хусусиятлари // “Жамият ва бошқарув" журнали. 2010. 1-сон. - Б. 128129.

5. Почепцов Г.Т. Теория коммуникации. M. 2001. - C. 168.

6. Кривоносов А.Д. PR-текст в системе публичных коммуникаций. 2-е изд., доп. СПб., 2002. - С. $15-16$.

7. Yuldashbaevna, M. E. (2020). TheoreticalPractical And Epistemological Review Of Political Linguistics. The American Journal of Social Science and Education Innovations, 2(09), 470-483. 
The American Journal of Political Science Law and Criminology (ISSN - 2693-0803)

Published: April 30, 2021 | Pages: 171-176

Doi: https://doi.org/10.37547/tajpslc/Volume03Issue04-26

https://doi.org/10.37547/tajssei/Volume02 |

ssue09-72

8. Karimova, D. Лингвистика: важность, история и проблемы социолингвистики.

ОИ 2020, 1, 222-228.

https://doi.org/10.47689/2181-1415-vol1-

iss $1 / \mathrm{s}-\mathrm{pp} 222-228$ 